\title{
1. The Spread of Sorcery Killing and its Social Implications
}

\author{
Jack Urame
}

\section{Introduction}

In changing times when sickness and death can be scientifically explained, people continue to use sorcery and witchcraft beliefs to provide explanations and express their frustrations, confusion and stress when bad events happen. As a result, sorcery-related violence remains a huge social phenomenon in Papua New Guinea (PNG). Many families have suffered social stress from sorcery and witchcraft accusations, the marginalised have been displaced, the weak have been expelled from their communities and the defenceless have been killed in horrific circumstances.

Due to the diversity of sorcery and witchcraft beliefs and practices in PNG, sorcery-related killing is common in some societies but not in others. Media reports and stories are insufficient to generalise the phenomenon of sorcery killing or witch-hunts across PNG. In some societies people use direct physical force to kill, while in others people use counter-sorcery as a means of revenge without direct physical violence. Using physical violence in the pretext of sorcery is common in the highlands of PNG, in some parts of the Sepik, Madang, Bougainville and a few other places in PNG.

In this chapter, I will discuss two practical aspects of sorcery and witchcraft violence: accusations on the pretext of sorcery and witchcraft beliefs and the spread of sorcery killing or witch-hunts. I use the phrase 'sorcery-related killing' to refer to murder in the pretext of sorcery beliefs. Sorcery-related violence results from the belief that bad events are caused by evil people. I attempt to answer why sorcery accusations have increased in recent times and why the culture of killing has spread to new locations where it was uncommon or unknown in the past. To avoid terminology and conceptual inconsistency I use sorcery as an inclusive term for witchcraft. However, in some parts of PNG the term witchcraft or its pidgin equivalent sanguma is common. 


\section{Reported cases of sorcery-related killings}

Some few years back I conducted research on media reports of sorcery-related violence. My aim was to find out the extent sorcery cases were reported in the media, whether sorcery issues gained sufficient publicity and how the community, the police and the courts responded to sorcery cases. I searched in three PNG newspapers: the daily National and Post-Courier and the weekly Wantok papers. I did an electronic search through the papers, which were scanned and electronically stored in a database at the Melanesian Institute. I began this task in 2007 and selected newspaper reports from 2000 to 2006. Within that seven-year period I identified 75 cases with 147 victims reported in the newspapers (Zocca and Urame 2008). These figures were not convincing to claim that there was an average of 10.7 cases of sorcery accusations per year or a monthly average of 0.9 cases of sorcery involving torture and murder. However, those figures are likely to under-represent the real numbers because sorceryrelated violence was not always reported to appropriate authorities or to the media. The number of victims I identified in the media search was much lower than what was revealed in research conducted by the Melanesian Institute around the same period. For instance, Kundiawa Hospital in Simbu Province registered many sorcery victims who sought medical treatment but many of those cases were not reported in the media (Zocca 2009).

Comparing sorcery cases involving violence during that period, the Highlands Region was leading followed by Momase Region, Southern Region and New Guinea Islands Region. At present the sequence from highest to lowest cases of sorcery involving violence in the four regions still stands in this order. Since 2007, the number of cases involving torture and murder around the country has not been consistently followed up, therefore the actual figure is unknown. Without actual data it is difficult to establish the average number of killings annually in the country. However, from research conducted by the Melanesian Institute as well as cases reported in the media, sorcery killings have increased in recent times (Zocca 2009; Zocca and Urame 2008).

There are several factors why many sorcery-related cases have not been exposed in the media or in public. These are described below.

\section{Protection of the community}

Often sorcery-related killings are concealed within the clan or tribal communities. From the community's perspective, killing a suspected sorcerer is an act of defence for the good of the community. The young people in the communities who usually take the lead in accusations and killings are supported by the members of the community because the accusers are considered as defenders 
and protectors of the community. The negative response of the members of the community is influenced by this general perception; therefore sometimes they do not support the police or cooperate in police investigations on sorcery killing. Often members of the community are reluctant to report because of the belief that sorcerers are a threat to the well-being of the community and therefore must be removed.

\section{Fear of consequences}

Many cases have never been reported to appropriate authorities because people are afraid of risking their own lives. Those who attempt to report or defend the accused are often themselves in danger of being accused for supporting sorcerers or in danger of being labelled as sorcerers. Due to threats and intimidation, relatives and family members are afraid of losing their own lives if they report or retaliate. Fear of possible negative consequences continues to suppress people, hence sorcery-related violence often remains unreported.

\section{Lack of police presence}

Police response has been very limited. Not all sorcery-related violence has been attended to and followed up by police. There are several reasons why police response has been minimal. Some of these are unavailability of vehicles, no fuel, lack of manpower and police expectations for complainants to pay money or buy diesel before cases are attended to. These are expressions of police reluctance or ignorance to reduce sorcery-related violence. When this happens people simply give up, seek other alternatives or resort to further violence.

\section{Geographic limitations}

Many villages are situated in remote places and the nearest government stations from which to seek help are located kilometres away from the villages. Due to geographic hardship and absence of government stations, many cases of sorcery-related violence are not made known to the public or attended to by state authorities. Sometimes cases are not attended to because the roads have deteriorated or bridges collapsed, preventing access to the area so sorcery cases remain isolated from the police or other state authorities.

\section{The culture of silence}

The factors listed above contribute to the culture of silence. In places where sorceryrelated violence occurs, people remain silent and accept sorcery killing as a way of life because the belief in sorcery is deeply embedded in Melanesian spirituality. 
Violence was a way of life in traditional societies and continues to be so across societies in Melanesia today, because people are reluctant or do not easily accept alternative world views. When sorcery talk begins, young people in the community often claim authority over others and exercise control over the situation. They intimidate members of the community who may feel threatened and powerless and do not speak up or speak against the young people. So the culture of silence on one hand promotes sorcery violence, and on the other hand prevents cases of sorcery-related violence from being reported to state authorities.

\section{New trends of sorcery killing}

In Melanesian societies where social relationships and kinship ties are central to life in rural communities, sorcery violence often breaks families and clan communities apart.

There are several reasons why family members suffer sorcery accusations. First, it is believed that the blood of the relatives is 'hot', so sorcery power is inwardly projected, therefore sorcery issues begin within the family. Second, the power of sorcery is effective within the family line so when someone dies, an immediate family member is most likely to be accused. Third, sorcery power is believed to be passed from one person to another through the social network of family and lineage. Fourth, when family members react against the accusation or when they do not support the community, they are blamed for protecting or supporting the sorcerer. Fifth, the accusers feel much safer blaming people within the family than outside the family due to fear of retaliation from accusations directed at people from another line or clan.

However, despite the general perception of the connection between sorcery and family violence, in the past accusations were targeted at individuals and rarely on families. Today, accusations involving families and groups are increasing. For instance, from the 75 cases of sorcery accusation I identified in the media reports, half of them involved families or groups of people who are socially related. Here are some examples: in one case, three families were tortured and their houses burnt down completely; in another case, a family was held at gunpoint, slowly tortured for hours and eventually murdered; in a different case a husband was chased out of the community while his wife was chopped to death and their children were left in complete desolation; in a further case, a baby was split in half when the mother who was carrying the baby tried to avoid a bush knife that was swung at her. The list of such violent attacks on families is not exhaustive and new incidents are added every year.

The traditional patterns of sorcery accusation have also changed. Various techniques of accusation were used by perpetrators, ranging from verbal abuse 
to physical assault and murder in various forms. Particularly in the highlands where sorcery-related killing is common, some of the punishment methods now applied to suspected sorcerers are new compared to methods used in traditional societies. For instance, suspected sorcerers are tied with cords, publicly interrogated and disgraced, thrown alive into rivers, tied and thrown alive over cliffs, locked indoors and burnt alive, buried in pit toilets, suffocated, hung on trees, slowly tortured for hours or days, burnt with flammable liquids, axed to death, chopped with bush knives, shot with guns, tied up and burnt with hot iron, stripped naked and tortured in public, or tied with rope and dragged behind moving vehicles. These are some methods used recently to eliminate suspected sorcerers from communities.

Sorcery-related violence using modern technologies like guns, vehicles, iron, axes, bush knives or chemicals on families indicates the collapse of social order in communities and the lack of social control in the midst of social crisis. The victims are those perceived to be on the periphery of society and the marginalised whose social status is considered insignificant by the community. Victims of sorcery violence are often old people and women who are not able to defend themselves. Due to their weak social status in the community, they become vulnerable to sorcery-related violence when social crises like sickness and death strike the community.

\section{Factors of increase in sorcery killing}

In traditional societies, sorcery-related killing was not common in all parts of PNG. In places where sorcery belief was strong, traditional social structures provided control mechanisms through which issues were addressed, and therefore sorcery-related killing was minimal. In chieftain societies there was hierarchal order, which kept the behaviour of young people in control. The chiefs often relied on the sorcerer for his advantage and for the good of the community. Therefore in times of social crisis sorcerers were not penalised or removed from the community by young people. In traditional big-man societies, particularly in the highlands, young people respected the authority of traditional leaders. In Simbu Province, for example, sorcery issues were publicly discussed in the presence of the members of the community and not among a few in private to execute murder. Previously, in times of social disorder, young people, whose social status was less significant in the community, were afraid to act violently against suspected sorcerers without the approval of the traditional leaders.

However, today there is a changing trend where sorcery-related violence is often initiated and executed by young people in isolation and the community becomes aware only during or after the accusation or removal of the sorcerers. Unlike in 
traditional societies, today traditional leaders are often reluctant to intervene when sorcery accusations occur because they are afraid of being physically attacked or blamed for being sorcerers themselves. Compared to tribal warfare, which often caused extreme social stress and communal disorder, sorcery-related violence in the past was less destructive because of social controls within clans. In some societies, suspected sorcerers were publicly disgraced, but they were rarely burnt, hanged or killed as happens today in some PNG societies.

Today sorcery-related violence, in particular witch-hunts, are spreading from one place to another. In societies where sorcery killing seldom happened, it occurs quite frequently today, and in places where it was never experienced before, it is beginning to happen. These new trends of sorcery violence bring new challenges and therefore it is important to understand the underlying factors of the increase and spread of sorcery killing. Some of the contributing factors are discussed below.

\section{Lack of development}

Lack of development causes social stress among people and contributes to the increase in sorcery-related violence. New development alters people's perception of life while rapid changes create confusion, disorientation and social tension. While lack of development is evident in many places, people's expectations for a better life are high. However, when expectations are not met, people resort to sorcery as a means of seeking answers or as a shortcut to meet their expectations. Lack of economic development in rural areas, failure in business, failure in school examinations, failure to find employment and so on are also attributed to sorcery. As a result of development failures, innocent people are blamed and accused on the pretext of sorcery.

\section{Collapse of traditional systems}

In today's changing PNG, our Melanesian social structures and systems, which hold societies together, are becoming weak or gradually collapsing. Village elders and traditional leaders are no longer being respected by young people who seek identity and recognition in society. Social cohesion within families and clan communities declines as sorcery-related violence causes social fragmentation. Traditional values of communal life and social systems are increasingly being challenged as the trend towards materialism and individualism increases. This results in the culture of greed and corruption, and the social and economic life of sharing, caring and helping is gradually losing its value. The collapse of traditional social systems promotes the culture of sorcery accusations. 


\section{Economic imbalance}

Economic disparity also contributes to the increase in sorcery violence. The rising cost of living in the country creates inequality between those who have and those who do not, and the gap between them widens. This often leads to jealousy within communities between the economically advantaged and disadvantaged groups. As a result, when sorcery issues arise, people take advantage of the situation to release their frustration. The discontent of economic imbalances in society is often expressed through the existing belief in sorcery.

\section{Lifestyle diseases}

The increase in lifestyle diseases in PNG today also contributes to sorcery accusations. The availability of imported food like lamb flaps, alcohol and fast food, which contain too much sugar and fat, affects the health of many people and causes new sicknesses, which were unknown in traditional societies. Many people also lack knowledge about health, hygiene and healthy lifestyles. As a result, when people die of lifestyle diseases, innocent people are blamed. People die young due to risky behaviour and unhealthy lifestyles, yet relatives often attribute the deaths to sorcery.

\section{Generational conflict}

The breakdown in social order and generational conflict between the old and young also leads to the increase in sorcery accusations. Today a new social group is emerging in the communities. They are known as 'drug bodies', made up of young people who have no perspective in life and who have no hope for the future. They become a threat to communities because of their association with drugs and violence. In times of social crisis such as sickness and death, sorcery discussions are often led by drugtakers and accusations are made by these young people.

\section{Lack of information or misguided information from medical workers}

Sometimes there is insufficient or irrelevant information from hospitals. In my research with the Melanesian Institute on sorcery, I found that families of patients were not properly informed when the patient could not recover. When medical help was exhausted and the patient was at the point of death, medical workers say it is 'sik bilong ples' therefore 'go long ples na stretim tok', which implies that the sickness is caused by someone at home, so go home and seek answers there. Nonsense talk like this confirms the belief that sicknesses are 
caused by evil people and therefore sorcerers must be blamed. When patients die at the hospital, doctors provide medical reports but, despite this, people continue to accuse innocent people of sorcery and witchcraft (see also Cox and Phillips, Chapter 2, this volume).

\section{Lack of positive knowledge}

People are so deeply rooted in their belief systems that they are not able to accept alternative world views. People with positions of authority and responsibilities, such as medical workers, police, church pastors and educated elites, continue to believe in the power of sorcery and witchcraft. They sometimes become a party to sorcery violence through direct involvement in it, or through their influence on others. This implies that in PNG the level of education, social standing, profession and leadership of many people do not play a significant role in influencing people's belief systems. Thus lack of positive knowledge can lead to the increase in sorcery violence.

\section{Spread of sorcery killing}

In the past, witch-hunts were practised only in some societies. While witchhunts were uncommon in traditional Enga society and in parts of Western Highlands, Eastern Highlands, Southern Highlands and Hela provinces, they were common in Simbu and other parts of Eastern Highlands, Western Highlands and Jiwaka provinces. However, in recent times, sorcery killing has spread to societies where the practice was unknown or infrequent in the past. Today there are reported cases of people being accused or murdered for sorcery in almost all the highlands provinces.

When the Melanesian Institute conducted research on sorcery in PNG, I did over 50 interviews between 2006 and 2008 in various locations (Urame 2009). After the publication of that research I continued to do random interviews with various people from different provinces to understand the spread of sorcery killing. I interviewed people from different places in Morobe, Madang, Eastern Highlands, Simbu, Jiwaka, Western Highlands and Enga provinces. They were a mixture of ordinary people, educated elites, village leaders, students, church workers, academics and missionaries. In the interviews I asked, 'Is witch-hunt common in your area and if so was it also practised in the past or is it a new culture in your area? If it is a new culture how did it spread into your area?' Except in Simbu, respondents from other provinces gave similar responses. They claimed that witch-hunts are a new social phenomenon and they are not sure how it was brought into their area. In an interview in 2007 with a church pastor from Enga, I found that sorcery accusations were uncommon 
although the belief in harmful spirits was already present in traditional Enga spirituality. The common threat to human life in Enga was tribal enemies and not sorcery. However, in an interview in 2014 with another pastor from Enga, I found that the culture of sorcery accusations is now beginning to penetrate the province. It has spread from Western Highlands to Wapenamanda in Enga Province. Cases of sorcery fear and accusations were already reported in Porgera and Wapenamanda. Therefore, it is very likely that in a few years the culture of witch-killing will grip Enga society as in other highlands societies.

Several factors have contributed to the spread of witch-hunts in recent times. These are described below.

\section{Geographic mobility}

Geographic mobility has increased and people continue to move between villages and towns. When people migrate they go with their beliefs and in times of sickness, death or other misfortune they use their beliefs to resolve crises. Today witch-hunts are no longer isolated in villages or remote parts of the country, but have spread to towns and urban settlements.

\section{Intermarriage}

In traditional societies, marriage was limited to neighbouring clans or tribes and rarely extended beyond those limits. The pattern of marriage is changing today. People are exposed to new cultures through intermarriage. They come into contact with people whose belief systems are different from their own. As a result, traditional beliefs such as sorcery and its related violence spread from one cultural group to another through marriage connections and social networks.

\section{Media}

Media publicity of sorcery killing also contributes to the spread of sorcery violence. When what happens in one part of the country is published in the media, it spreads to the other parts of the country. While the media serves its purpose of publicity, people digest the information and reinterpret it in the context of their own belief systems. The information either informs or reinforces the existing beliefs. Therefore media publicity of sorcery cases has in a way unintentionally fuelled the spread of the belief and the violence associated with it. 
Talking it Through

\section{Importation of culture}

People have selective memories and tend to remember events or stories that confirm their beliefs. Hence sorcery accusations confirm and reinforce their beliefs. People hear or learn about sorcery violence from other places and they try it out in their own cultures. The common belief in bad spirits and evil powers provides the basis through which sorcery accusation has spread from one society to another.

\section{Conclusion}

Sorcery accusations are used as a means of revenge, resolving conflict and settling hostilities, and as a means to redress social and economic imbalances in society. The perpetrators of sorcery violence are not strangers, but people who are biologically or socially related to the accused. For example, in a personal interview with a highly educated man, he told me of his approval for the death of his biological mother in 2010 in Simbu. He ordered the young men in his village to murder her because he believed that she planned to bewitch him. In another personal interview in 2011 with a man in Simbu, he said he mobilised with his clansman and murdered his own niece because they suspected her of causing the death of a cousin brother. There are examples of many similar cases.

If sorcery killing is permitted to happen between people who are socially connected, there must be another underlying value that lies deep within society other than the value of the social bond. In the centre of society lies man's religious beliefs - be it sorcery or Christianity or something else. The value of religious belief outweighs the value of social bond. In several interviews, this idea was explicitly expressed. One said, 'if we don't remove the sorcerers we will all die and our clan will be empty'. Another said, 'if the government imposes the death penalty on the young men in the communities for witch-hunts our defence will be removed and the sorcerers will be happy and wipe us all out'. If this is indicative of a mindset dilemma influenced by their Melanesian world view, it is not sufficient to address sorcery-related violence on the surface, but necessary to go a step further to understand the Melanesian belief systems. Therefore the most crucial attempt would be to work towards changing the mindset of the people, so that through the process of change sorcery belief and its consequential violence may one day be eliminated. 


\section{References}

Bartle, N. 2005. Death, Witchcraft and the Spirit World in the Highlands of Papua New Guinea. Point No. 29. Goroka: Melanesian Institute.

Bogner, P. 1988. Sangguma - Schwarze Magie der Papua: Bericht aus einer anderen Wirklichkiet. München, Germany: Wilhelm Goldmann Verlag.

Bowden, R. 1987. Sorcery, Illness and Social Control in Kwoma Society. In M. Stephen (ed.) Sorcerer and Witch in Melanesia. Carlton: Melbourne University Press, 183-207.

Brown, P. 1997. Kumo Witchcraft at Mintima, Chimbu Province. Oceania XLVIII(1):26-29.

Fortune, R.F. 1963. Sorcery of Dobu: The Social Anthropology of the Dobu Islanders of the Western Pacific. New York: E.P. Dutton.

Gesch, P. 1979. Magic as a Process of Social Discernment. In N.C. Habel (ed.) Powers, Plumes and Piglets: Phenomena of Melanesian Religion. Australian Association for the Study of Religions, 137-48.

Gibbs, P. 2010. Witch Killing and Engendered Violence in Simbu. Catalyst 40(1):24-64.

Hughes, J.R. 1985. Chimbu Worlds: Experiences of Continuity and Change by a Papua New Guinea Highland People. PhD thesis, La Trobe University, Melbourne.

Kelly, R. 1976. Witchcraft and Sexual Relations. In P. Brown and G. Buchbinder (ed.) Man and Woman in the New Guinea Highlands. Washington DC: American Anthropological Association, 36-53.

Kelly, R.C. 1993. Constructing Inequality: The Fabrication of a Hierarchy of Virtue among the Etoro. Ann Arbor: University of Michigan Press.

Kuehling, S. 2005. Dobu: Ethics of Exchange on a Massim Island, Papua New Guinea. Honolulu: University of Hawai'i Press.

Leonard, B.G. 1973. Sorcery and Witchcraft. In I. Hogbin (ed.) Anthropology in Papua New Guinea. Carlton: Melbourne University Press, 182-86.

Lindenbaum, S. 1978. Sorcery and Danger. Oceania XLVI(1):68-75.

Lindenbaum, S. 1979. Kuru Sorcery: Disease and Danger in the New Guinea Highlands. California: Mayfield Publishing Company. 
Talking it Through

Longgar, W. 2009. Sorcery and Christianity in the Gazelle Peninsula. In F. Zocca (ed.) Sanguma in Paradise: Sorcery, Witchcraft and Christianity in Papua New Guinea. Point No. 33. Goroka: Melanesian Institute, 305-59.

MacDonald, M. 1981. Sorcery and Society. Catalyst 11(3):168-79.

MacDonald, M.N. 1990. Mararoko: A Study in Melanesian Religion. New York: Peter Lang.

Malinowski, B. 1985. Crime and Custom in Savage Society. Totowa, NJ: Rowman \& Allanheld.

Sillitoe, P. 1987. Sorcery Divination among the Wola. In M. Stephen (ed.) Sorcerer and Witch in Melanesia. Carlton: Melbourne University Press, 121-46.

Steadman, L. 1978. Sorcery and Danger. Oceania XLVI(1):114-21.

Stephen, M. 1979. Sorcery, Magic and the Mekeo World View. In N.C. Habel (ed.) Powers, Plumes and Piglets: Phenomena of Melanesian Religion. Australian Association for the Study of Religions, 149-60.

Stephen, M. 1987. Constructing Images of Power. In M. Stephen (ed.) Sorcerer and Witch in Melanesia. Carlton: Melbourne University Press, 249-99.

Strathern, M. 1972. Women In Between: Female Roles in a Male World: Mount Hagen, New Guinea. London: Seminar Press.

Strathern, M. 1988. The Gender of the Gift. Berkeley: University of California Press.

Trompf, G.W. 1991. Melanesian Religions. Cambridge: Cambridge University Press.

Trompf, G.W. 1994. Payback: The Logic of Retribution in Melanesian Religions. Cambridge: Cambridge University Press.

Urame, J. 2008. A Review on Some Researches Done on the Belief and Practices of Sorcery and Witchcraft in the Simbu Province. Catalyst 38(2):181-201.

Urame, J. 2009. Sorcery Beliefs, Practices and Mission among the Kote of Finschaffen, Morobe Province. In F. Zocca (ed.) Sanguma in Paradise: Sorcery, Witchcraft and Christianity in Papua New Guinea. Point No. 33. Goroka: Melanesian Institute, 96-166.

Zocca, F. (ed.) 2009. Sanguma in Paradise: Sorcery, Witchcraft and Christianity in Papua New Guinea. Point No. 33. Goroka: Melanesian Institute. 
Zocca, F. 2010. Gender and Accusation of Malevolent Sorcery and Witchcraft in Papua New Guinea. Catalyst 40(2):192-206.

Zocca, F. and J. Urame 2008. Sorcery, Witchcraft and Christianity in Melanesia. Melanesian Mission Studies No. 5. Goroka: Melanesian Institute. 
This text is taken from Talking it Through: Responses to Sorcery and Witchcraft Beliefs and Practices in Melanesia, edited by Miranda Forsyth and Richard Eves, published 2015 by ANU Press, The Australian National University, Canberra, Australia. 